12-30-1993

\title{
Jonathan Pollard: A More Genuine Notion of Justice
}

Kenneth Lasson

University of Baltimore School of Law, klasson@ubalt.edu

Follow this and additional works at: http://scholarworks.law.ubalt.edu/all_fac

Part of the International Law Commons, Military, War, and Peace Commons, and the National Security Law Commons

\section{Recommended Citation}

Jonathan Pollard: A More Genuine Notion of Justice, The Baltimore Sun, December 30, 1993

This Editorial is brought to you for free and open access by the Faculty Scholarship at ScholarWorks@University of Baltimore School of Law. It has been accepted for inclusion in All Faculty Scholarship by an authorized administrator of ScholarWorks@University of Baltimore School of Law. For more information, please contact snolan@ubalt.edu. 


\section{Related Articles}

Don't free Jonathan Pollard

March 7, 2013

Is Jonathan Pollard a Camp David bargaining chip?

July 14, 2000

Here's why the Pollard case simply won't go away

November 25, 1992

Let Him Rot

December 30, 1993

Obama should free Pollard

February 27, 2013

\section{Find More Stories About}

Sentence

Jonathan Pollard

\section{Jonathan Pollard: a More Genuine Notion of Justice}

$\begin{array}{lll}\text { Recommend } & \sqrt{0} & \\ \text { Tweet } & \bullet \vdots & 0 \\ & \bullet \vdots & \mathbf{G + 1}\end{array}$

December 30, 1993 | By KENNETH LASSON

When President Clinton implored the American public to see "Schindler's List," the quintessential horror film about the Holocaust, some of Jonathan Pollard's supporters saw it as a hopeful sign.

Perhaps the president, visibly moved by the film, would sympathize with the moral impulse that drove Pollard to give vital defense information to Israel. Perhaps he'd likewise equate Nazi Germany with demonic Iraq. Perhaps Mr. Clinton, currently compiling his own list of presidential pardons, would see to it that the horrendous life sentence handed Pollard in 1985 be commuted to time served.

One hopes that the president will pay little heed to the editorials gratuitously denouncing Pollard, or to the news stories quoting unnamed sources in the intelligence community coming in from the cold to pepper the Oval Office with passionate pleas against any clemency.

Particularly galling, though, are the potshots from two former Justice Department prosecutors -- the politically ambitious Joseph DiGenova and his former assistant David Geneson -- who effectively bargained Pollard out of a trial by promising not to seek a maximum sentence. Now they've come out of the woodwork to argue that Pollard deserved exactly what he got, slinging new charges never brought before a judge or jury.

All the latter-day accusations, whether based on fact or passion, are virtually unassailable because they either relate to "classified" data or reflect "informed" opinion. Thus Mr. DiGenova can escape unchallenged when he declares to the New York Times that "This was the largest physical compromise of United States classified information in the 20th century."

The validity of that claim, of course, can never be effectively tested because of the plea agreement on which the prosecutors subsequently reneged.

Mr. Geneson's assertion in the Washington Post that the government "fulfilled its obligations under the [plea] agreement" disingenuously ignores the finding of the D.C. Court of Appeals, which decided (2-1) against Pollard on narrow procedural grounds but did not deny the more substantive point made by dissenting judge Steven Williams: "The government's conduct in this case resulted in a fundamental and complete miscarriage of justice."

What defendant, after all, would bargain away his right to a fair trial in return for a life term?

Some newspapers have likewise betrayed their biases. To assert that "some American Jewish groups have taken up [Pollard's] ++ case . . . in a largely intramural debate" [the Times] is to grossly distort the truth.

In fact, a large and diverse cross-section of individuals and groups from around the world has protested the outrageously disproportionate nature of Pollard's sentence. (The average penalty for a similar offense is four years.)

They realize that, in contrast to many other spies convicted of more serious crimes, Pollard was never accused of intending to harm the United States. Nor was he ever charged with treason -- except by the former secretary of defense, Caspar Weinberger. Now even Mr. Weinberger, perhaps rendered contrite by his own recent pardon, says that he wouldn't oppose reducing Pollard's life term.

That's small satisfaction to the millions of Americans, from all faiths and backgrounds, who have gone much further to express their support. They include Sen. Carol Mosely-Braun, the Rev. Benjamin Hooks, Cardinal Bernard Law, Nobel laureate Elie Wiesel, evangelist Pat Robertson, Father Theodore Hesburgh. They also include the city councils of Chicago, Los Angeles, Miami Beach and New York.

No other person convicted either of treason or of Pollard's lesser transgression has ever garnered as much public and private support, nor from as wide a cross-section of academics, laymen, professionals and politicians. Certainly no one has ever attracted as much sympathy from local, state and foreign governments.

Nor has any of this to do with an intramural debate among Jewish groups. Much to the contrary, they have shown unusual unanimity in calling for clemency. Everyone from the Canadian Jewish Congress to the Chief Rabbis of Denmark, France and South Africa have sent letters to President Clinton. Virtually all the major American Jewish organizations have done the same.

Mr. DiGenova first showed his sense of fair play on the courthouse steps when Pollard was sentenced. Although the government had not asked for a life term, its chief prosecutor said even then that "he will never see the light of day."

Here's hoping that Mr. DiGenova is wrong -- that the American people's more genuine notion of justice will prevail -- and that Jonathan Pollard will indeed make Clinton's List.

Kenneth Lasson is a law professor at the University of Baltimore.

\section{MORE:}

How to treat bone spurs 


\begin{tabular}{|l|} 
Grandson, 12, admits killing Shabazz But he says her \\
death was not intended \\
'Blushing' ear is no cause for alarm \\
Senator's wife recounts terror, helplessness as victim of \\
obsessed stalker \\
Minor's future arrives early Rookie didn't expect to make \\
a start at third this season \\
Wrestler found shot dead family has lost five sons Latest \\
tragedy apparently a suicide
\end{tabular}

\section{THE BALTIMORE SUN}

Index by Keyword | Index by Date | Privacy Policy | Terms of Service

Please note the green-lined linked article text has been applied commercially without any involvement from our newsroom editors, reporters or any other editorial staff. 